\title{
Institusi Perkhidmatan Kemanusiaan dan Pembangunan Keluarga di Unit Perunding dan Pembangunan Keluarga Jabatan Agama Islam Wilayah Persekutuan Kuala Lumpur
}

\author{
ZAINAB ISMAIL
}

\begin{abstract}
The aim of this article is to describe the role of the Unit of Consultants and Family Development (UCFD) at Jabatan Agama Islam Wilayah Persekutuan (JAWI) in family development in Wilayah Persekutuan Kuala Lumpur. This article presents evidence that although this institution had established quite along time ago, marital conflicts and divorces in the state are still on the growing. Based on this evidence we can say that the program of family development conducted by UCFD, JAWI is not so sucsessful. However this article shows that the couples attending the counseling sessions at UCFD gained a lot of assistence from dakwah given by the counselors.
\end{abstract}

\begin{abstract}
ABSTRAK
Tujuan artikel ini bertujuan untuk memperihalkan peranan Unit Perunding dan Pembangunan Keluarga (UPPK) di Jabatan Agama Islam Wilayah Persekutuan Kuala Lumpur dalam konteks pembangunan keluarga di Wilayah Persekutuan Kuala Lumpur. Artikel ini membincangkan isu UPPK, JAWI sebagai institusi yang telah lama wujud, namun konflik dalam perkahwinan dan perceraian di Wilayah Persekutuan Kuala Lumpur masih terus berlaku. Berasaskan kepada fenomena ini dapat diandaikan program pembangunan keluarga yang ditawarkan oleh UPPK, JAWI adalah kurang berjaya. Bagaimanapun artikel ini menunjukkan pasangan yang mengikuti sesi kaunseling di UPPK, JAWI mendapat banyak manfaat daripada kaunselor yang menerapkan unsur dakwah dalam sesi kaunseling.
\end{abstract}

\section{PENGENALAN}

Di Malaysia akhir-akhir ini masalah keluarga seperti keruntuhan institusi keluarga, semakin ramai wanita melambatkan perkahwinan, meningkatnya jumlah kelahiran anak di luar nikah, bersekedudukan, penderaan kanak-kanak, penagihan dadah, lari dari rumah dan pelbagai masalah kekeluargaan yang 
5. Perceraian semakin meningkat

6. Jumlah ibu bapa tunggal semakin ramai

7. Semakin ramai anak-anak hidup dalam kemiskinan

8. Perkahwinan semula semakin meningkat

Walaupun rumusan ini hasil pemerhatian ke atas aspek kekeluargaan di negara maju, tetapi rumusan seperti ini boleh diperhatikan ke atas negara lain, termasuk Malaysia. Berasaskan Laporan Banci Penduduk dan Perumahan Malaysia (Jabatan Perangkaan Malaysia, 2001), wujud perubahan dalam konteks kekeluargaan di Malaysia, khususnya dalam konteks proporsi penduduk balu/ duda ataupun penduduk yang bercerai/berpisah. Pada tahun 1980 terdapat sejumlah 5.7 peratus penduduk Malaysia yang berstatus balu/duda. Angka ini menurun sedikit kepada 4.6 peratus dalam tahun 2000. Dalam konteks bercerai/ berpisah pula angka ini ialah 1.4 peratus dalam tahun 1980 dan menurun kepada 0.9 dalam tahun 2000. Jika ditinjau dari segi jantina, terdapat perbezaan yang agak ketara di antara penduduk perempuan dengan penduduk lelaki. Penduduk perempuan jauh melebihi penduduk lelaki dalam kedua-dua aspek ini. Perbezaan ini disebabkan kadar kematian yang lebih tinggi di kalangan penduduk lelaki berbanding perempuan. Penduduk lelaki juga mempunyai kecenderungan yang lebih untuk berkahwin semula jika kematian pasangan ataupun jika bercerai. Dari segi taburan geografi, terdapat perbezaan yang agak ketara antara negeri. Penduduk yang bercerai/berpisah adalah lebih tinggi di negeri seperti di Kelantan, Perlis, Terengganu dan Kedah. Bagi negeri lain, peratusan ini lebih kecil. Perbezaan ini dapat diterangkan berasaskan fakta bahawa penduduk yang tinggal di negeri yang lebih rendah tahap pembandarannya mempunyai peratusan bercerai/berpisah yang lebih tinggi berbanding negeri yang lebih maju dan lebih tinggi tahap pembandarannya (Jadual 1).

Jadual 1

Taburan Peratusan Balu/Duda dan Bercerai/Berpisah Penduduk Melayu Berumur 15 Tahun dan Lebih Semenanjung Malaysia Mengikut Negeri (2000)

Negeri

Johor

Kedah

Kelantan

Melaka

Negeri Sembilan

Pahang

Perak

sambungan Jadual 1)
Balu/Duda

4.5

5.7

6.1

5.7

5.0

4.2

6.3
Bercerai/Berpisah

0.6

1.0

1.7

0.8

0.7

0.7

0.7 
lain, bukan lagi menjadi masalah yang bersifat individu, tetapi sudah menjadi masalah sosial yang memerlukan perhatian serius daripada pelbagai pihak. Antara faktor yang menyumbang kepada berlakunya pelbagai masalah dalam institusi keluarga adalah disebabkan oleh pembangunan sosial dan ekonomi negara yang pesat. Yaakob Harun (1992) menyatakan proses pembandaran menyebabkan berlakunya perubahan fungsi keluarga. Fungsi keluarga, seperti fungsi ekonomi, pendidikan, keagamaan, perlindungan dan rekreasi bagi keluarga di bandar banyak yang telah diambilalih oleh institusi lain. Akibatnya terjadilah perubahan peranan dan kuasa dalam keluarga. Pemindahan sebahagian fungsi keluarga kepada institusi lain seperti kilang dan industri telah melemahkan institusi keluarga tersebut. Ini menyebabkan keluarga itu sendiri sudah kekurangan keupayaan untuk menyelesaikan segala persoalan keluarga atau rumah tangga yang timbul.

Akibat masalah yang melanda rumah tangga ini, penerimaan masyarakat ke atas perkhidmatan kemanusiaan sebagai satu bentuk sistem sokongan menjadi semakin penting. Institusi kaunseling umpamanya sudah dapat diterima kewujudannya dalam masyarakat. Kebanyakan pasangan yang mengalami masalah rumah tangga di bandar-bandar besar, mendapatkan perkhidmatan kaunseling sebagai satu cara menyelesaikan permasalahan rumah tangga. Bagaimanapun tidak semua proses bantuan kaunseling yang diberikan kepada pasangan yang bermasalah berakhir dengan kejayaan.

\section{MASALAH DALAM INSTITUSI KELUARGA MELAYU DI MALAYSIA}

Masyarakat Melayu hari ini khususnya, serta masyarakat sejagat umumnya, sedang dilanda pelbagai masalah, sama ada berpunca daripada dalam keluarga ataupun luar keluarga. Salah satu masalah besar keluarga ialah masalah perpecahan rumah tangga. Perpecahan rumah tangga, atau disebut juga sebagai keruntuhan keluarga, menjadi perkara yang lumrah dalam masyarakat sejagat, termasuk masyarakat Melayu di Malaysia. Para sarjana pelbagai ilmu pada umumnya menghubungkan masalah perpecahan rumah tangga atau keruntuhan keluarga ini dengan perubahan sosial yang berlaku dalam masyarakat. Shaffer (2000) umpamanya melalui pemerhatian ke atas hasil banci di Amerika Syarikat dan hasil penyelidikan oleh pelbagai penyelidik di negara maju, merumuskan bahawa perubahan sosial yang pesat telah melahirkan lapan ciri utama keluarga masa kini, iaitu;

1. Semakin ramai orang dewasa yang hidup sendirian

2. Kebanyakan orang semakin melewatkan umur perkahwinan

3. Jumlah anak dalam keluarga semakin berkurangan

4. Semakin ramai wanita yang bekerja di luar rumah 
kahwin paksa, kurang didikan agama, curang, keras, cerewet, gila, campur tangan mertua, politik (berlainan fahaman), bergurau, pendapatan tidak mencukupi, suka sama suka, isteri engkar, tiada persefahaman, isteri bisu, isteri mandul, masalah kesihatan (isteri tidak boleh mengandung), terlibat dengan najis dadah (suami), cacat anggota, kurang sabar, hamil sebelum kahwin, judi, minum arak, zina, suami dalam penjara, suami tidak memberi nafkah, suami ada perempuan lain, isteri ditinggalkan suami (ghaib), kezaliman atau penganiayaan terhadap isteri, isteri melayan lelaki lain atau tidak senonoh serta pengabaian terhadap nafkah dan kasih sayang (Fail Rekod Bahagian Informasi Islam, JAKIM, 1998).

Secara umumnya dapat dikatakan sebab-sebab tersebut berpunca daripada pasangan itu sendiri dan orang ketiga. Aspek yang berpunca daripada pasangan ialah seperti suami isteri tidak bertanggungjawab, cemburu, kahwin paksa, kurang didikan agama, curang, keras, cerewet, gila, poligami, masalah seks, bergurau, pendapatan tidak mencukupi, suka sama suka, isteri engkar, tiada persefahaman, isteri bisu, isteri mandul, masalah kesihatan (isteri tidak boleh mengandung), terlibat dengan najis dadah (suami), cacat anggota, kurang sabar, hamil sebelum kahwin, judi, minum arak, zina, suami dalam penjara, suami tidak memberi nafkah, suami ada perempuan lain, isteri ditinggalkan suami (ghaib), kezaliman atau penganiayaan terhadap isteri, isteri melayan lelaki lain atau tidak senonoh serta pengabaian terhadap nafkah dan kasih sayang. Manakala aspek yang berpunca daripada orang ketiga ialah campur tangan mertua, dan berlainan fahaman politik. Bagi memulihkan kestabilan perkahwinan ini, terdapat ayat alQur'an yang menunjukkan pendekatan kaunseling sebagai salah satu pendekatan perkhidmatan kemanusiaan. Ayat al-Qur'an tersebut bermaksud:

Dan perempuan-perempuan yang kamu bimbang derhaka (nusyuz) hendaklah kamu menasihati mereka dan (jika mereka berdegil) tinggalkanlah (pulaukanlah) mereka di tempat tidur, dan (kalau juga mereka masih degil) pukullah mereka (dengan pukulan ringan yang bertujuan mengajarnya). Kemudian jika mereka taat kepada kamu, maka janganlah kamu mencari-cari jalan untuk menyusahkan mereka (Surah al-Nisa': 34).

\section{TRADISI PERKHIDMATAN KEMANUSIAAN DALAM BUDAYA MASYARAKAT ISLAM}

Keluarga adalah institusi yang penting dalam agama Islam. Ini adalah kerana keluarga berperanan mencorak bentuk hubungan anak-anak dengan Penciptanya. Pincang keluarga akan pincanglah keimanan anak-anak. Keluarga yang pincang tentunya tidak akan mampu untuk memupuk keimanan di kalangan anak-anak. Oleh sebab itu dalam tradisi masyarakat Islam, pembangunan keluarga adalah 


$\begin{array}{lcc}\text { Negeri } & \text { Balu/Duda } & \text { Bercerai/Berpisah } \\ \text { Perlis } & 5.9 & 1.3 \\ \text { Pulau Pinang } & 4.9 & 0.7 \\ \text { Selangor } & 3.3 & 0.6 \\ \text { Terengganu } & 5.1 & 1.3 \\ \text { Wilayah Persekutuan Kuala Lumpur } & 3.5 & 0.9 \\ \text { Malaysia } & 4.6 & 0.9\end{array}$

Sumber: Dihitung daripada pelnagai jadual dlm. Ciri-ciri Pendidikan dan Sosial Penduduk, Banci Penduduk dan Perumahan Malaysia, 2001.

Data di atas adalah berasaskan kepada jumlah keseluruhan penduduk Melayu yang berumur 15 tahun dan ke atas, dan ia didapati selari dengan data yang diperolehi daripada Jabatan Kemajuan Islam Malaysia (JAKIM). Mengikut Fail Rekod Perkahwinan, Perceraian dan Rujuk, Bahagian Informasi Islam, JAKIM (1998a, 1998b \& 1998c), dalam tempoh antara 1980-1990 terdapat 850,654 pasangan berkahwin di seluruh Malaysia. Daripada jumlah itu 167,012 (19.63\%) pasangan telah bercerai. Jika perceraian ini dianalisis mengikut negeri, iaitu berasaskan jumlah perkahwinan yang terdaftar, peratus yang paling tinggi terdapat di Wilayah Persekutuan, Kuala Lumpur (32.37 peratus). Ini bererti Wilayah Persekutuan, Kuala Lumpur adalah negeri yang paling tinggi peratusan perceraiannya di Malaysia dalam tempoh tersebut. Negeri lain yang juga tinggi ialah Terengganu (27.41 peratus), Perlis (22.91 peratus) dan Kedah (21.27 peratus). Peratus perceraian di negeri lain adalah di bawah 20.0 peratus (Zainab Ismail \& Wan Ibrahim Wan Ahmad, 2004).

Berasaskan Statistik Perkahwinan Seluruh Malaysia 1990-2004 (Jabatan Kemajuan Islam Malaysia, KESUMA 2005) dan Statistik Perceraian Seluruh Malaysia 1990-2004 (Jabatan Kemajuan Islam Malaysia, KESUMA 2005), dapat diperhatikan wujud perubahan dalam konteks kekeluargaan di Malaysia. Dalam tahun 2004, terdapat 111,944 pasangan berkahwin di seluruh Malaysia. Daripada jumlah itu, 16,509 (14.75\%) pasangan telah bercerai. Jika perceraian ini dianalisis mengikut negeri, peratus yang paling tinggi adalah terdapat di Selangor (18.99\%). Ini bererti Selangor adalah negeri yang paling tinggi peratusan perceraiannya di Malaysia dalam tahun 2004. Negeri lain yang juga tinggi ialah Kelantan (11.82\%), Johor (10.24\%), Perak (9.13\%), Kedah (8.93\%), Kuala Lumpur (7.85\%), dan Terengganu (7.10\%). Peratus perceraian di negeri lain adalah di bawah 6.0 peratus. Angka ini didapati menurun banyak jika dibandingkan dengan statistik perceraian antara tahun 1980-1990. Bagaimanapun ia tetap menunjukkan perceraian masih berlaku.

Terdapat pelbagai sebab yang mendorong berlakunya perceraian. Antaranya ialah poligami, cemburu, masalah seks, suami isteri tidak bertanggungjawab, 
iaitu mereka (yang tetap mengerjakan sembahyangnya). (Surah al-Hujurat:19)

Manakala perintah Allah (s.w.t.) ke atas semua suami supaya memainkan peranan sebagai ketua keluarga jelas dalam firman-Nya yang bermaksud:

Kaum lelaki itu adalah pengurus dan pemimpin yang bertanggungjawab terhadap kaum perempuan, oleh kerana Allah telah melebihkan orang-orang lelaki (dengan beberapa keistimewaan) atas orang-orang perempuan dan (juga) kerana orang-orang lelaki telah membelanjakan (memberi nafkah) sebahagian dari harta mereka. (Surah al-Nisa':34)

Daripada keenam-enam ayat al-Qur'an tersebut, dapat dirumuskan bahawa Islam amat menitikberatkan hubungan kasih sayang antara suami dan isteri, etika pergaulan antara suami dan isteri, serta ketaatan kepada perintah Allah (s.w.t.) bagi menjamin keharmonian institusi keluarga. Persoalannya ialah bagaimanakah untuk menerapkan kesedaran hubungan dalam keluarga menurut Islam, dan menerapkan kesedaran mengenai ketaatan kepada Allah (s.w.t.)? Dalam konteks ini, perkhidmatan kemanusiaan menjadi satu keperluan dalam institusi keluarga pada hari ini. Salah satu bentuk perkhidmatan kemanusiaan yang diperlukan ialah kaunseling keluarga.

Dalam konteks masyarakat Muslim di Malaysia, walaupun perkhidmatan kemanusiaan merupakan program yang masih baru, khususnya jika ditinjau dari segi perkhidmatan kaunseling yang disediakan di Jabatan Agama Islam, tetapi tradisi memberikan bantuan kepada orang yang bermasalah sudah menjadi budaya sejak lama dalam masyarakat Islam. Perkhidmatan seperti ini boleh dikatakan telah wujud sejak era dakwah Nabi Muhammad (s.a.w.) iaitu sejak Baginda dilantik sebagai Rasul pada tahun 610M. Hal ini disebabkan peranan Rasulullah (s.a.w.) sendiri pada masa itu yang menjadi tempat kepada umat Islam mengadu masalah, mendapat tunjuk ajar ketika menghadapi krisis atau masalah dan mendapat bantuan bagi menyelesaikan masalah yang dialami. Namun, proses Rasulullah (s.a.w.) membantu umat Islam memahami, menghadapi, menerima dan menyelesaikan masalah yang dihadapi, tidak dikenali sebagai perkhidmatan kaunseling, sebaliknya ia lebih terkenal dengan nama sistem hisbah (Zainab Ismail \& Wan Ibrahim, 2004).

Mengikut Hassan Langgulung (1990), hisbah adalah satu konsep syarak yang bererti perintah mengerjakan kebaikan ( $m a^{c} r u f$ ) yang sudah nampak ditinggalkan dan larangan mengerjakan kemungkaran yang sudah nampak dikerjakan serta membaiki hubungan antara sesama manusia. ${ }^{\mathrm{c} A b d}$ al-Karim Zaidan (1997) menyatakan hisbah ialah fungsi keagamaan yang terkandung dalam al-amr bi al-ma ${ }^{c} r_{s} f$ wa al-nahy ${ }^{c}$ an al-munkar yang merupakan fardu bagi 
amat dipentingkan. Banyak ayat-ayat al-Qur'an yang menekankan tentang pentingnya hubungan kasih sayang dalam keluarga. Antaranya ialah firman Allah (s.w.t.) yang bermaksud:

Di antara tanda kebesaran-Nya adalah diciptakan-Nya buatmu isteri-isteri agar kamu memperoleh ketenangan hati dengannya, serta membuatmu berkasih sayang. Hal itu merupakan petunjuk tentang kebesaran-Nya buat mereka yang mahu berfikir. (Surah al-Rum: 21)

Allah (s.w.t.) juga menuntut golongan suami agar menghormati isteri mereka, dan mewajibkan golongan suami mempergauli isteri mereka secara baik, sekalipun mereka tidak suka atau tidak senang untuk mempergauli isteri mereka tersebut. Antara ayat al-Qur'an berkaitan dengan isu pergaulan suami isteri ini ialah firman Allah (s.w.t.) yang bermaksud:

Pergaulilah mereka dengan baik. Bila kamu tidak menyukainya, mungkin sesuatu yang tidak kamu sukai itu diadakan Tuhan kebaikan yang banyak di dalamnya. (Surah al-Nisa':19)

Dalam surah yang lain, Allah (s.w.t.) berfirman dengan maksudnya:

Hak untuk isteri yang patut diterimanya daripada suaminya seimbang dengan kewajipannya terhadap suaminya dengan baik. (Surah al-Baqarah: 228)

Bagi menjamin keharmonian institusi keluarga, Allah (s.w.t.) menegaskan bahawa setiap anggota keluarga wajib peka kepada suruhan dan tuntutan agama. Suruhan agama yang utama dan menjadi asas keharmonian institusi keluarga ialah mendirikan ibadah sembahyang dan memastikan suami memainkan peranan sebagai ketua keluarga. Perintah sembahyang ini jelas dalam firman Allah (s.w.t.) yang bermaksud:

Dan dirikanlah sembahyang (dengan tetap), sesungguhnya sembahyang itu mencegah daripada perbuatan yang keji dan mungkar. (Surah al- ${ }^{\mathrm{c} A n k a b u t: ~ 54)}$

Perintah sembahyang ini juga dijelaskan oleh Allah (s.w.t.) dalam firmanNya yang bermaksud:

Sesungguhnya manusia itu dijadikan bertabiat resah gelisah (lagi bakhil kedekut); Apabila ia ditimpa kesusahan, ia sangat resah gelisah dan apabila ia beroleh kesenangan, ia sangat bakhil kedekut, kecuali orang-orang yang mengerjakan sembanhyangnya; 
memelihara akhlak masyarakat, menghalang perbuatan bidcah, melindungi tanah perkuburan daripada dijadikan tempat minum dan berfoya-foya atau sebagai tempat berjual beli, memelihara perilaku antara jantina di jalan raya atau permandian awam serta menyiasat sebarang usaha menyembunyikan atau menghalang kebenaran. Diwan al-Hisbah juga menyelia perkahwinan semula balu dan wanita yang diceraikan dengan menyediakan calon suami yang sesuai, bertanggungjawab dan berkemampuan (Abdul Malek,1995).

\section{PERKHIDMATAN KEMANUSIAAN DI UNIT PERUNDING DAN PEMBANGUNAN KELUARGA, JAWI}

Dalam konteks masyarakat Malaysia kini, perkhidmatan kemanusiaan, khususnya perkhidmatan kaunseling telah dijadikan sebagai satu kaedah di beberapa Jabatan Agama Islam di Malaysia, sebagai usaha untuk membantu pasangan suami isteri yang mengalami konflik rumah tangga mewujudkan kembali persefahaman dan mencari jalan mengeratkan hubungan kasih sayang di antara mereka serta menangani keruntuhan institusi kekeluargaan. Antara Jabatan Agama Islam yang mengambil inisiatif mewujudkan unit kaunseling di jabatan masing-masing ialah Jabatan Agama Islam Wilayah Persekutuan, Kuala Lumpur, Jabatan Hal Ehwal Agama Islam Terengganu, Jabatan Agama Islam Selangor, Jabatan Agama Islam Johor, Jabatan Agama Islam Melaka, Jabatan Agama Islam Negeri Sembilan, Jabatan Agama Islam Sabah dan Jabatan Agama Islam Sarawak.

Semua aduan daripada pasangan suami isteri yang bermasalah di JabatanJabatan Agama Islam ini dikendalikan oleh Pegawai Hal Ehwal Agama dengan cara memberi bimbingan, kaunseling, dan nasihat. Setiap pasangan yang mengalami masalah dalam rumah tangga akan dirujuk kepada Pegawai Hal Ehwal Agama yang berperanan sebagai kaunselor. Dalam sesi kaunseling tersebut, para pasangan yang bermasalah akan dibantu untuk membuat penerokaan, menyelesaikan masalah, dan membuat keputusan terhadap masalah yang mereka alami. Ringkasnya, melalui sesi kaunseling para pasangan yang bermasalah akan memperolehi celik akal.

Jabatan Agama Islam Wilayah Persekutuan, Kuala Lumpur (JAWI) adalah salah satu Jabatan Agama Islam di Malaysia yang menawarkan perkhidmatan kemanusiaan. Dari segi sejarah, JAWI telah beroperasi hampir 16 tahun di Malaysia sebagai sebuah institusi agama yang menguruskan urusan yang berhubung dengan hal ehwal agama Islam. Ia ditubuhkan dengan tujuan; "untuk melahirkan sebuah masyarakat maju yang menjadikan Islam satu cara hidup sempurna berasaskan al-Qur'an dan al-Sunnah; dan melahirkan masyarakat yang terpelihara dari segi aqidah dan syariah" (JAWI, http://www.islam.gov. my/jawi/objektif.htm 1. 1999:1). 
sesiapa yang memerintah kaum Muslimin. Ibn Khaldun (1981) pula berpendapat hisbah adalah satu jawatan dalam urusan agama yang bertanggungjawab untuk menegakkan kebaikan dan mencegah kemungkaran. Manakala al-Faruqi, \& Lois Lamy (1986) berpendapat hisbah adalah satu institusi yang berkonsepkan al-amr bi al-mac ${ }^{c} f$ wa al-nahy ${ }^{c}$ an al-munkar. Walaupun hisbah ini tidak dijalankan secara profesional dan formal pada zaman Rasulullah (s.a.w.), namun al-Mawardi berpendapat ia berjaya membentuk sahsiah dan tingkah laku anggota masyarakat Islam untuk hormat, berkasih sayang dan bertimbang rasa ( ${ }^{\mathrm{c}} \mathrm{Abd}$ alKarim Zaidan, 1997). Kejayaan perlaksanaan hisbah ini mempunyai hubungan yang rapat dengan dua firman Allah (s.w.t.) yang bermaksud:

Wahai orang-orang yang beriman! Hendaklah kamu menjadi orang-orang yang sentiasa menegakkan keadilan, lagi menjadi saksi (yang menerangkan kebenaran) kerana Allah, sekalipun terhadap diri kamu sendiri (Surah al-Nisa': 135)

Dan orang-orang yang beriman, lelaki dan perempuan, setengahnya menjadi penolong bagi setengahnya yang lain, mereka menyuruh membuat kebajikan dan melarang daripada berbuat kejahatan, dan mereka mendirikan sembahyang dan memberi zakat serta taat kepada Allah dan Rasul-Nya, mereka itu akan diberi rahmat oleh Allah (Surah al-Taubat: 71).

Oleh kerana hisbah banyak memberi faedah kepada umat Islam, pada zaman Saiyidina Umar al-Khattab, satu institusi yang diberi nama Diwan al-Hisbah telah ditubuhkan. Penubuhan Diwan al-Hisbah ini adalah langkah awal ke arah menjadikan hisbah sebagai satu profesion dalam program dakwah. Pada permulaannya, Saiyidina Umar al-Khattab melantik muhtasib yang berkebolehan, daripada golongan khalifah, amir, peniaga, pengusaha, peladang, guru, imam masjid, bapa, ibu, belia, beliawanis, suami, isteri, rakan, kaum kerabat atau jiran yang dianggap bertanggungjawab ke atas kebajikan orang awam dan untuk membimbing manusia kepada kebaikan. Selaras dengan itu sistem hisbah dijalankan di pelbagai tempat, seperti di rumah, masjid, pasar ataupun jalan raya. Untuk memenuhi tugas sebagai muhtasib, mereka ini dikehendaki keluar kepada orang awam untuk menyiasat dan memastikan syariat Islam dilaksanakan (al-Faruqi \& Lois Lamya’, 1986).

Pada zaman al-Mahdi iaitu Khalifah Abbasiyyah yang ketiga, Diwan alHisbah telah diperkenalkan sebagai sebuah jabatan yang tidak memisahkan antara politik dengan agama. Sejak penubuhannya, DÔwan al-Hisbah dikembangkan sebagai sebuah institusi separa kehakiman yang menguruskan perkara-perkara yang tidak terikat atau dikawal sepenuhnya oleh undangundang Syariah. Diwan al-Hisbah ini bertanggungjawab dalam pelbagai tugas seperti mentadbir aliran dan tukaran wang, timbangan dan nilai wang syiling, 
Islam di seluruh negara (JAWI, http://www.islam.gov.my/jawi/terbaru.htm1. 1999:1). Bagi melancarkan perlaksanaan tugas kepada umat Islam, JAWI telah menetapkan fungsinya kepada lima aspek:

1. Melaksanakan program pendidikan umat Islam.

2. Melaksanakan program ekonomi umat Islam.

3. Mewujudkan aktiviti sosial dan kebajikan bagi faedah umat Islam.

4. Menyediakan tempat-tempat ibadat dengan secukupnya.

5. Meningkatkan perkhidmatan agama kepada umat Islam.

Bagi melaksanakan fungsi tersebut, JAWI telah menubuhkan bahagian dan unit tertentu. Sejak tahun 1984 tersebut, beberapa bahagian yang wujud di bawah pentadbiran JAWI adalah seperti Bahagian Istinbat, Bahagian Amar Maaruf, Bahagian Baitulmal Zakat, Bahagian Pentadbiran dan Kewangan serta Bahagian Pentadbiran Undang-Undang Syariah. Di bawah bahagian-bahagian ini diletakkan pula beberapa unit tertentu. Di bawah Bahagian Pentadbiran Undang-Undang Syariah umpamanya diletakkan Unit Penguatkuasa/Pendakwa, Unit Perunding Keluarga (al-Irshad al- ${ }^{c}$ Aliy) dan Unit Urusan Kekeluargaan (Ahwal Shakhsiah).

Sebelum tahun 1984, unit yang bertanggungjawab menyediakan perkhidmatan kaunseling ialah Unit Perundingan dan Khidmat Nasihat. Bermula tahun 1984, Unit Perunding Keluarga (al-Irshad al- ${ }^{c}$ Aliy) yang bertanggungjawab ke atas perlaksanaan meningkatkan perkhidmatan agama kepada umat Islam telah dinaikkan taraf kepada Unit Perunding dan Pembangunan Keluarga (UPPK). Penubuhan UPPK ini merupakan inisiatif JAWI bagi membantu pasangan suami isteri yang mengalami ketegangan rumah tangga mencari jalan mengeratkan kembali hubungan kasih sayang dan mewujudkan semula suasana nyaman dan harmoni dalam rumah tangga mereka.

Unit Perunding dan Pembangunan Keluarga (UPPK) telah beroperasi lebih 20 tahun di Bahagian Pentadbiran Undang-Undang Syariah. Pada peringkat awal penubuhan, semua Pegawai Hal Ehwal Islam yang bertugas di Bahagian Pentadbiran Undang-Undang Syariah terlibat dalam mengendalikan urusan nikah, cerai dan rujuk serta memberi khidmat nasihat kepada pasangan suami isteri yang mengalami konflik dalam rumah tangga. Menyedari pentingnya perkhidmatan nasihat kepada pasangan suami isteri yang bermasalah dalam rumah tangga, pada tahun 1976, JAWI telah menubuhkan Unit Perunding Keluarga (al-Irshad al-c Aliy) dan diletakkan di bawah Bahagian Pentadbiran Undang-Undang Syariah. Di bawah Unit Perunding Keluarga (al-Irshad al${ }^{c}$ Aliy) tersebut diwujudkan pula Unit Perundingan dan Khidmat Nasihat yang bertanggung jawab mengendalikan aduan berkaitan konflik dalam rumah tangga. Unit ini ini tidak mempunyai kuasa untuk membuat sebarang keputusan ke atas pasangan yang bermasalah dalam rumah tangga. Segala keputusan yang dibuat ke atas pasangan yang bermasalah dalam rumah tangga perlu dirujuk kepada kadhi. Begitu juga sekiranya Pegawai Perunding Keluarga tidak 
Objektif JAWI ini adalah untuk melahirkan insan salih yang beramal dengan ajaran al-Qur'an dan al-Sunnah serta berpegang teguh dengan aqidah dan syariah. Ini menunjukkan JAWI adalah sebuah organisasi yang bertanggungjawab mengendalikan hal ehwal agama Islam dan berfungsi sebagai satu badan dakwah yang berusaha menegakkan kebaikan dan mencegah kemungkaran (al-amr bi al-mac $r_{s} f$ wa al-nahy ${ }^{c}$ an al-mungkar).

Pada 1 Februari 1974, berikutan penubuhan Wilayah Persekutuan Kuala Lumpur, Majlis Agama Islam Wilayah Persekutuan (MAIWP) telah ditubuhkan. MAIWP adalah sebuah badan agama Islam yang bertanggungjawab mengendalikan segala urusan yang berhubung dengan hal ehwal agama Islam di Wilayah Persekutuan. Dengan tertubuhnya MAIWP pada 1 Februari 1974, JAWI telah diwujudkan untuk menjadi urusetia kepada MAIWP. Pada waktu itu, JAWI diletakkan di bawah urusetia Majlis Kebangsaan Bagi Hal Ehwal Islam, Malaysia (MKI), yang kemudiannya dinaikkan taraf sebagai Bahagian Agama, Jabatan Perdana Menteri. Bahagian Agama ini, kemudiannya dikenali sebagai Bahagian Hal Ehwal Islam (BAHEIS), Jabatan Perdana Menteri. Sebelum penubuhan MAIWP dan JAWI, semua urusan berhubung hal ehwal agama Islam di Kuala Lumpur dikendalikan oleh Jabatan Agama Islam Selangor (JAIS). Apabila JAWI ditubuhkan pada 1974, semua urusan yang berhubung dengan hal ehwal agama Islam di Kuala Lumpur dikendalikan oleh JAWI (JAWI, http://www.islam.gov.my/jawi/sejarah.htm 1. 1999:1).

Pada tahun 1976, JAWI diletakkan di bawah Kementerian Wilayah Persekutuan. Berikutan permansuhan kementerian itu pada tahun 1987, kedudukan JAWI di bawah Kementerian Wilayah Persekutuan juga dimansuhkan, dan diletakkan pula di bawah Bahagian Kemajuan Wilayah Persekutuan, Jabatan Perdana Menteri hingga sekarang (JAWI, http://www. islam.gov.my/jawi/sejarah.htm 1. 1999:1). Dari segi tempat operasi, pada peringkat awal penubuhan, JAWI memulakan operasinya di Bangunan Baitulmal Wilayah Persekutuan, Jalan Ipoh, Kuala Lumpur. Pada akhir tahun 1989, operasi JAWI telah dipindahkan ke Bangunan Sulaiman, Jalan Damansara, Kuala Lumpur. Pada 1 Januari 1997, selaras dengan pembangunan dan kemajuan Islam yang bertambah mantap di Malaysia, Jabatan Kemajuan Islam Malaysia (JAKIM) telah ditubuhkan oleh kerajaan Malaysia bagi mengambilalih kuasa dan peranan BAHEIS (JAWI, http://www.islam.gov.my/jawi/profil/sejarah. htm1.1999:1).

Sehubungan itu, perubahan kuasa dan peranan BAHEIS kepada JAKIM, pengurusan JAWI juga turut mengalami perubahan. Pada Februari 1998, pengurusan JAWI yang berada di bawah Bahagian Kemajuan Wilayah Persekutuan, Jabatan Perdana Menteri telah diletakkan di bawah JAKIM. Perubahan yang berlaku ke atas pengurusan JAWI ini selaras dengan dasar kerajaan untuk menyelaraskan pengurusan hal ehwal berkaitan dengan 
konflik dalam rumah tangga untuk memahami masalah yang dihadapi oleh mereka dan mencari jalan penyelesaian atau keputusan demi kebaikan rumah tangga mereka. Pendekatan kedua-dua fungsi UPPK ini adalah selaras dengan konsep dakwah yang menuntut kebaikan ditegak dan kemungkaran dicegah (al-amr bi al-macruf wa al-nahy ' ${ }^{c}$ an al-mungkar). Oleh kerana UPPK berada di bawah pengurusan Bahagian Pentadbiran Undang-Undang Syariah, seorang Pegawai Hal Ehwal Ugama Islam telah dilantik sebagai Ketua Penolong Pengarah Kanan di Bahagian Pentadbiran Undang-Undang Syariah. Ketua Penolong Pengarah Kanan ini bertanggung jawab kepada lima orang Pegawai Hal Ehwal Ugama Islam yang dilantik sebagai Penolong Pengarah Perunding dan Pembangunan Keluarga di UPPK dan lima orang Pegawai Hal Ehwal Ugama Islam yang dilantik sebagai Pendaftar Nikah, Cerai dan Rujuk di Unit Pendaftaran Nikah, Cerai dan Rujuk. Kelima-lima orang Penolong Pengarah Perunding dan Pembangunan Keluarga ini diberi tanggungjawab mengendalikan sesi kaunseling kepada pasangan yang bermasalah mengikut kawasan masingmasing iaitu Kuala Lumpur, Setapak, Kepong, Sungai Besi dan Damansara. Bagi memudahkan urusan pengendalian sesi kaunseling kepada pasangan yang bermasalah dalam rumah tangga, kelima-lima Penolong Pengarah Perunding dan Pembangunan Keluarga ini dibantu oleh Penyelia Pusat Khidmat Sosial, Pembantu Hal Ehwal Islam Kanan, Pembantu tadbir, Jurutaip, Pembantu Am Rendah dan Pekerja Rendah Awam (Zainab Ismail, 2001).

Sebagai satu unit yang mengendalikan segala urusan yang berkaitan dengan perundingan dan pembangunan keluarga, UPPK menyediakan khidmat kaunseling kepada masyarakat Muslim di Wilayah Persekutuan, Kuala Lumpur. Dalam proses mengendalikan khidmat kaunseling dan menerima pasangan suami isteri yang bermasalah sebagai klien, terdapat lapan langkah yang diikuti oleh UPPK, iaitu (Zainab Ismail, 2001):

1. Memberi penjelasan kepada pengadu

Pembantu Hal Ehwal Islam (pembantu kepada Penolong Pengarah Perunding dan Pembangunan Keluarga) yang bertugas di kaunter akan memberi penjelasan kepada pengadu tentang syarat yang perlu dipenuhi sebelum mendapatkan perkhidmatan kaunseling di UPPK. Syarat-syarat tersebut ialah:

i. Klien mestilah individu yang bermastautin dalam Wilayah Persekutuan. Untuk mengenal pasti identiti klien, klien dikehendaki menunjukkan alamat dalam kad pengenalan atau alamat dalam bil-bil bayaran seperti bil air, telefon atau seumpamanya atau surat akuan daripada ketua imam atau juru nikah di tempat individu klien itu tinggal.

ii. Klien dikehendaki mengemukakan sijil nikah dan kad pengenalan serta salinan-salinannya.

iii. Klien dikehendaki mengisi borang aduan yang disediakan oleh UPPK. 
dapat menyelesaikan kes-kes tertentu secara kaunseling, mereka dikehendaki merujukkan pasangan yang terlibat dalam kes tersebut kepada kadhi. Fenomena ini timbul disebabkan Unit Perundingan dan Khidmat Nasihat diletakkan di bawah kuasa kadhi.

Mengikut Sulaiman Endut (1998), pada tahun 1984 Akta Undang-Undang Keluarga Islam (Wilayah-wilayah Persekutuan 1984) (Akta 303) telah digubal dan dilaksanakan. Implikasi daripada penggubalan dan perlaksanaan Akta Undang-Undang Keluarga Islam (Wilayah-wilayah Persekutuan 1984) (Akta 303) tersebut telah menyebabkan berlaku suatu perubahan pengurusan di Bahagian Pentadbiran Undang-Undang Syariah. Unit Perunding Keluarga ( $a l$ Ir shad al- ${ }^{c}$ Aliy) telah dinaikkan taraf kepada Unit Perunding dan Pembangunan Keluarga (UPPK), bagi mengambil alih kuasa dan peranan Unit Perunding Keluarga (al-Irshad al--Aliy). Dengan wujudnya UPPK dalam tahun 1984, semua kes kaunseling telah diletakkan di bawah kuasa Penolong Pengarah Perunding dan Pembangunan Keluarga. Kadhi atau Pendaftar Nikah, Cerai dan Rujuk tidak lagi mempunyai kuasa untuk mencampuri urusan kes kaunseling yang dijalankan oleh Penolong Pengarah Perunding dan Pembangunan Keluarga. Mereka ini hanya bertanggungjawab ke atas urusan yang berkaitan dengan pendaftaran perkahwinan, perceraian dan rujuk sahaja.

Perkhidmatan kaunseling yang dijalankan oleh UPPK pada tahun 1984 telah beroperasi di Bangunan Baitulmal Wilayah Persekutuan, Jalan Ipoh, Kuala Lumpur. Pada akhir tahun 1989, berikutan dengan perpindahan tempat operasi JAWI ke Bangunan Sulaiman, Jalan Damansara, Kuala Lumpur, UPPK juga turut berpindah dan menjalankan operasinya di Bangunan Sulaiman, Jalan Damansara, Kuala Lumpur (JAWI, t.th.: Brosur Perkhidmatan Kaunseling Menenangkan Suasana Konflik). Objektif UPPK secara tersurat tidaklah diketahui. Namun begitu, terdapat dua perkara utama yang dititikberatkan dalam penubuhan UPPK iaitu:

1. Untuk memberi perkhidmatan nasihat kepada pasangan suami isteri yang mengalami konflik dan keadaan tidak serasi dalam rumah tangga.

2. Untuk bertanggungjawab sepenuhnya mengendalikan semua aduan berkaitan dengan konflik rumah tangga.

Mengikut brosur Perkhidmatan Kaunseling Menenangkan Suasana Konflik yang diterbitkan oleh JAWI (t.th.), fungsi UPPK ialah:

1. Membantu pasangan suami isteri dan keluarga yang bermasalah mencari jalan mengeratkan hubungan kasih sayang dan kemesraan.

2. Menghindarkan perceraian yang membawa risiko permusuhan kekeluargaan.

Daripada kedua-dua fungsi UPPK ini jelas menunjukkan bahawa UPPK adalah suatu unit alternatif kepada pasangan suami isteri yang mengalami 
syarat-syarat yang ditetapkan UPPK. Kebanyakan pengadu yang tidak dapat memenuhi syarat-syarat yang telah ditetapkan oleh UPPK dan tidak dapat dibukakan fail kes untuk mereka ialah mereka yang tidak mempunyai sijil nikah yang sah kerana berkahwin di Thailand, berkahwin secara sindiket dan tidak bermastautin di Wilayah Persekutuan, Kuala Lumpur. Terdapat juga pengadu yang tidak dibukakan fail kes kerana mereka hanya ingin mendapatkan pandangan daripada pihak kaunselor mengenai masalah yang berlaku dalam rumah tangga mereka sahaja.

4. Membuka fail kes pengadu dan memberi nombor rujukan

Bagi pengadu yang memenuhi syarat-syarat yang telah ditetapkan oleh UPPK, borang UPPK 1 yang telah diisi oleh mereka akan dimasukkan ke dalam fail kes dan diberi nombor rujukan oleh Pembantu Hal Ehwal Islam (pembantu kepada Penolong Pengarah Perunding dan Pembangunan Keluarga). Nombor rujukan yang diberi kepada fail kes mereka merujuk kepada bilangan pengadu yang ke berapa yang membuat aduan dan tahun pengadu tersebut membuat aduan di UPPK. Jika pengadu adalah klien yang ke-83 membuat aduan dalam tahun 1999, maka nombor rujukan yang diberi kepada fail kes pengadu tersebut ialah 83/99.

5. Memberi kad temu janji kepada pengadu

Sekiranya terdapat pengadu yang sangat memerlukan perkhidmatan kaunseling, Pembantu Hal Ehwal Islam (pembantu kepada Penolong Pengarah Perunding dan Pembangunan Keluarga) akan merujuk pengadu tersebut kepada kaunselor pada hari yang sama aduan dibuat. Dalam keskes yang tidak memerlukan kaunseling di buat dengan segera, Pembantu Hal Ehwal Islam (pembantu kepada Penolong Pengarah Perunding dan Pembangunan Keluarga) akan membawa fail kes pengadu tersebut kepada kaunselor untuk ditentukan tarikh temu janji kaunseling. Tarikh temu janji kaunseling akan dicatatkan oleh Pembantu Hal Ehwal Islam di dalam satu kad temu janji yang di dalamnya dicatatkan nombor fail, tarikh aduan, nama pengadu, nama kena adu (pasangan pengadu), nama perunding (kaunselor), tarikh temu janji dan masa temu janji untuk sesi kaunseling. Setelah itu Pembantu Hal Ehwal Islam menyerahkan kad temu janji kepada pengadu.

6. Menghantar surat kepada pengadu dan pasangan pengadu

Selain daripada kad temu janji, Pembantu Hal Ehwal Islam (pembantu kepada Penolong Pengarah Perunding dan Pembangunan Keluarga) akan menghantar surat jemputan temu janji atau notis kepada pengadu dan yang kena adu secara berasingan. Tujuannya ialah sebagai peringatan dan undangan kepada mereka bagi menghadiri sesi kaunseling pada tarikh dan masa yang telah ditetapkan. 
Hanya kes-kes yang berlaku dalam perkahwinan sahaja yang boleh dibukakan fail bagi pengadu. Kes-kes yang berlaku dalam perkahwinan ialah seperti kes suami tidak memberi nafkah, kes isteri curang, kes suami suka memukul atau kes suami tidak mengaku melafazkan cerai. Bagi pengadu yang mengalami konflik selepas berlakunya perceraian, UPPK tidak boleh membuka fail kes mereka dan tidak boleh menyediakan perkhidmatan kaunseling kepada mereka. Tetapi, bagi membantu pengadu berkenaan mencari jalan penyelesaian, pihak UPPK akan mengarahkan agar mereka pergi membuat pengaduan di mahkamah syariah.

2. Memberi borang UPPK 1 kepada pengadu

Setelah pengadu diberi penjelasan tentang syarat-syarat yang perlu mereka penuhi, Pembantu Hal Ehwal Islam (pembantu kepada Penolong Pengarah Perunding dan Pembangunan Keluarga) yang bertugas di kaunter akan memberikan borang UPPK 1 kepada pengadu untuk diisi.

3. Menerima borang UPPK 1 daripada pengadu

Pembantu Hal Ehwal Islam (pembantu kepada Penolong Pengarah Perunding dan Pembangunan Keluarga) akan mengambil semula borang UPPK 1 yang telah diisi oleh pengadu. Tujuannya ialah untuk mengenal pasti identiti pengadu tersebut dan memastikan semua dokumen yang menjadi syarat untuk mendapatkan kaunseling dilampirkan. Sekiranya pengadu memenuhi syarat-syarat yang telah ditetapkan, fail kesnya akan dibuka. Sebaliknya, jika pengadu tersebut tidak dapat memenuhi syarat-syarat yang telah ditetapkan oleh UPPK, fail kesnya tidak dapat dibuka.

Bagaimanapun, Pembantu Hal Ehwal Islam (pembantu kepada Penolong Pengarah Perunding dan Pembangunan Keluarga) akan menyerahkan borang UPPK 1 yang telah diisi oleh pengadu kepada desk officer. Kemudian, Pembantu Hal Ehwal Islam (pembantu kepada Penolong Pengarah Perunding dan Pembangunan Keluarga) akan mengarahkan pula pengadu tersebut bertemu dengan desk officer. Desk officer ialah kaunselor yang bertugas secara bergilir-gilir setiap hari untuk mengendalikan kaunseling dan kebiasaannya dia tidak akan membuat temu janji dengan mana-mana pengadu pada hari dia bertugas sebagai desk officer. Sesi kaunseling yang berlaku di antara pengadu yang tidak dibukakan fail dengan desk officer ini akan tamat pada hari yang sama, sekalipun masalah yang dihadapi pengadu tersebut masih belum dapat di atasi dan pengadu masih memerlukan kaunseling. Kaunseling susulan hanya akan dapat dilakukan apabila pengadu berkenaan dapat memenuhi 
Dalam sesi kaunseling, pengadu (klien) akan membuat keputusan sama ada berdamai atau memilih kes ke mahkamah syariah. Sekiranya pengadu mengambil keputusan berdamai, fail kes mereka akan disimpan. Sekiranya mereka ingin mendapatkan kaunseling susulan, mereka boleh merujuk semula fail kes tersebut dan boleh mendapatkan perkhidmatan kaunseling daripada kaunselor yang sama.

Bagi kes yang tidak dapat diselesaikan melalui kaunseling dan pengadu memohon untuk merujukkan kesnya ke mahkamah syariah, fail kes mereka juga akan disimpan. Tetapi laporan lengkap mengenai perbincangan dalam sesi kaunseling akan diserahkan kepada pengadu untuk diserahkan kepada pihak mahkamah syariah semasa mereka membuat permohonan di mahkamah syariah. Selain perkhidmatan kaunseling ini, terdapat satu lagi perkhidmatan kaunseling yang dikendalikan oleh Pusat Khidmat Sosial (PKS). PKS merupakan sub unit yang diletakkan di bawah UPPK. Semua aktiviti kaunseling yang dikendalikan oleh PKS dijalankan pada hari petang Sabtu dan Ahad sahaja. Perkhidmatan kaunseling ini dijalankan di beberapa tempat di Wilayah Persekutuan, Kuala Lumpur. Perkhidmatan kaunseling PKS diberikan oleh mereka yang profesional, separa profesional dan juga mereka yang tidak profesional. Kaunselor profesional terdiri daripada kalangan kaunselor UPPK dan juga Pegawai Hal Ehwal Islam yang mendapat latihan kaunseling secara formal. Kaunselor yang separa profesional terdiri daripada para Pegawai Hal Ehwal Islam dan Pensyarah pusat-pusat pengajian tinggi yang tidak mendapat latihan dalam bimbingan dan kaunseling secara formal. Manakala perunding yang tidak profesional terdiri daripada Pembantu Hal Ehwal Islam dan imam-imam masjid. Walaupun ramai kaunselor yang bertugas di PKS terdiri daripada mereka yang tidak profesional dan separa profesional, mereka ini kerap diberikan pendedahan dan latihan kaunseling dari masa ke semasa supaya dapat memberi perkhidmatan perundingan yang lebih baik.

\section{PERANAN UPPK JAWI DALAM PEMBANGUNAN KELUARGA}

Walaupun UPPK sebagai institusi yang bertanggung jawab dalam pembangunan keluarga Islam, khususnya dalam konteks memberikan perkhidmatan kaunseling di kalangan pasangan yang bermasalah di Wilayah Persekutuan, Kuala Lumpur telah lama wujud, namun konflik rumah tangga dan perceraian masih terus berlaku. Jika dilihat daripada angka perceraian, didapati jumlah dan peratusan pasangan yang bermasalah dalam rumah tangga semakin bertambah. Sejak ditubuhkan pada 1974 - 2004, terdapat 87,799 pasangan mendaftarkan perkahwinan di Wilayah Persekutuan, Kuala Lumpur. Dalam tempoh tersebut 18,972 pasangan telah bercerai, iaitu melibatkan sejumlah 21.6 peratus pasangan. Arah aliran perceraian di Wilayah Persekutuan, Kuala Lumpur sejak penubuhannya sehingga tahun 2004 dapat dilihat melalui Jadual 2. Arah aliran 
7. Memberi khidmat kaunseling kepada pengadu dan yang diadu Perkhidmatan kaunseling di UPPK dijalankan oleh Penolong Pengarah Perunding dan Pembangunan Keluarga. Sebelum Penolong Pengarah Perunding dan Pembangunan Keluarga menjalankan sesi kaunseling kepada pengadu dan yang diadu, Pembantu Hal Ehwal Islam (pembantu kepada Penolong Pengarah Perunding dan Pembangunan Keluarga) akan menyediakan satu laporan khas mengenai perkahwinan pengadu dan yang diadu. Laporan mengenai perkahwinan pengadu dan yang diadu ini diisi dalam satu borang, iaitu borang Laporan Pembantu Pegawai Perunding. Terdapat enam perkara berkaitan perkahwinan pengadu dan yang diadu yang perlu diisi oleh Pembantu Hal Ehwal Islam dalam borang tersebut, iaitu;

i) Jenis perkahwinan sama ada poligami atau monogami serta isteri yang keberapa

ii) Dasar perkahwinan sama ada pilihan sendiri atau pilihan keluarga atau lain-lain

iii) Pernikahan kali ke berapa

iv) Pernah atau tidak bercerai, jika pernah bercerai, berapa kali cerai dan berapa bilangan talak serta bila tarikh nikah yang dahulu

v) Jantina anak dan berapa umur mereka

vi) Maklumat tambahan yang lain mengenai perkahwinan pengadu dan yang diadu jika ada.

Penolong Pengarah Perunding dan Pembangunan Keluarga akan merujuk kepada fail kes dan laporan lengkap mengenai perkahwinan pengadu dan yang diadu yang telah dilaporkan oleh Pembantu Hal Ehwal Islam (pembantu kepada Penolong Pengarah Perunding dan Pembangunan Keluarga) sebelum memulakan sesi kaunseling. Setelah sesi kaunseling tamat, Penolong Pengarah Perunding dan Pembangunan Keluarga bertanggungjawab menyediakan laporan lengkap mengenai apa yang dibincangkan di dalam sesi kaunseling. Laporan lengkap ini mencatatkan masalah yang dialami oleh pengadu dan yang diadu dalam rumah tangga, keputusan pengadu dan yang diadu selepas mengikuti sesi kaunseling serta ulasan dan cadangan Penolong Pengarah Perunding dan Pembangunan Keluarga terhadap pengadu dan yang diadu dalam borang Laporan Sesi Runding Cara: I/II/III.

Sesi kaunseling ini mungkin berjalan sekali, dua kali, tiga kali, atau beberapa kali. Kekerapan sesi kaunseling ini bergantung kepada perjalanan kaunseling dan keperluan pengadu sebagai klien. Ia juga bergantung kepada tahap kerumitan konflik yang dialami oleh pengadu dan yang diadu (pasangannya). Jika konflik yang dialami adalah rumit, sementara pengadu atau pasangannya tidak berhasrat untuk bercerai, terdapat kemungkinan sesi kaunseling akan berjalan banyak kali.

8. Menyimpan fail kes pengadu 
Sumber: Data 1974-1998 dihitung daripada Unit Pendaftaran Nikah, Cerai daan Rujuk, JAWI, 2000a, 2000b \& 2000c. Data 1999-2004 dihitung daripada JAKIM, KESUMA. 2005 (Statistik Perkahwinan Seluruh Malaysia 1990-2004 \& Statistik Perceraian Seluruh Malaysia 1990-2004).

Berasaskan semakin berleluasanya masalah kekeluargaan dalam masyarakat Islam di Wilayah Persekutuan, Kuala Lumpur pada hari ini, maka ia memberikan implikasi bahawa program pembangunan keluarga, khususnya perkhidmatan kaunseling yang ditawarkan oleh UPPK tidak semua dapat menyelesaikan atau menghindarkan pasangan bermasalah daripada bercerai (Zainab Ismail, 2001). Berasaskan semakin banyaknya jumlah perceraian di Wilayah Persekutuan, serta berasaskan tidak semua pasangan bermasalah yang mendapatkan khidmat kaunseling di UPPK berdamai atau berjaya diselamatkan, maka boleh dikatakan proses kaunseling di UPPK, JAWI juga kurang berjaya mempertahankan keharmonian institusi keluarga. Bagaimanapun, dalam konteks proses kaunseling di UPPK, Zainab Ismail (2001) menyatakan kurang berjayanya proses kaunseling ini ada kaitannya dengan tujuan responden yang datang ke UPPK itu sendiri. Pasangan yang membuat pengaduan di UPPK sebahagiannya bukan bertujuan menyelamatkan rumah tangga, tetapi untuk mempastikan hukum hakam undang-undang keluarga Islam berkaitan dengan tuntutan hak sahaja. Mereka menginginkan penjelasan lanjut mengenai hak dan tanggungjawab serta tuntutan harta sepencarian yang mungkin diperolehi sekiranya berlaku perceraian. Terdapat juga di antara klien yang datang mendapatkan perkhidmatan kaunseling di UPPK adalah klien yang mempunyai masalah yang sukar diselesaikan, dan bertekad untuk bercerai. Kedatangan mereka ke UPPK hanya dengan tujuan untuk mempercepatkan proses perceraian sahaja.

Oleh yang demikian, kayu ukur untuk menganalisis berjaya atau tidak peranan UPPK dalam program pembangunan keluarganya tidak dapat menggunakan kayu ukur tahap perceraian serta proses kaunseling yang berjaya mendamaikan pasangan bermasalah. Kejayaan institusi ini dalam program pembangunan keluarga dapat dilihat daripada proses dakwah yang diaplikasikan ke dalam proses kaunseling yang diperolehi di UPPK. Zainab Ismail (2001) mendapati proses kaunseling yang diberikan oleh kaunselor di UPPK berjaya menerapkan unsur dakwah dalam sesi kaunseling. Para klien yang datang mendapatkan sesi kaunseling di UPPK, walaupun akhirnya ada di antara mereka yang bercerai, tetapi mendapat banyak manafaat, khususnya dalam konteks hukum hakam kekeluargaan, hak dan tanggung jawab suami isteri, kelebihan bersabar, larangan bercerai, serta pelbagai nasihat dan pengajaran yang lain. Klien yang datang mendapatkan kaunseling pada umumnya tidak 
peratusan perceraian ini didapati turun naik, dengan peratusan yang paling rendah ialah 15.6 peratus (1976), sementara peratusan yang paling tinggi ialah 36.0 (1980). Pada tahun 2004, peratusan ini adalah agak tinggi iaitu 35.8 peratus.

Jadual 2

Peratus Perkahwinan dan Perceraian Wilayah Persekutuan, Kuala Lumpur Mengikut Tahun (1974 - 1999)

\begin{tabular}{|c|c|c|c|}
\hline Tahun & Perkahwinan & Perceraian & Peratusan Bercerai \\
\hline 1974 & 1212 & 208 & 17.2 \\
\hline 1975 & 1396 & 229 & 16.4 \\
\hline 1976 & 1573 & 245 & 15.6 \\
\hline 1977 & 1506 & 330 & 21.9 \\
\hline 1978 & 1576 & 339 & 21.5 \\
\hline 1979 & 1606 & 404 & 25.2 \\
\hline 1980 & 1610 & 579 & 36.0 \\
\hline 1981 & 1821 & 561 & 30.8 \\
\hline 1982 & 1879 & 624 & 33.2 \\
\hline 1983 & 2063 & 626 & 30.3 \\
\hline 1984 & 2290 & 698 & 30.5 \\
\hline 1985 & 2614 & 734 & 28.1 \\
\hline 1986 & 2478 & 845 & 34.1 \\
\hline 1987 & 2528 & 629 & 24.9 \\
\hline 1988 & 2144 & 486 & 22.7 \\
\hline 1999 & 2450 & 520 & 21.2 \\
\hline 1990 & 2750 & 552 & 20.1 \\
\hline 1991 & 2785 & 506 & 18.2 \\
\hline 1992 & 2930 & 621 & 21.2 \\
\hline 1992 & 2922 & 627 & 21.5 \\
\hline 1994 & 2947 & 608 & 20.6 \\
\hline 1995 & 2544 & 550 & 21.6 \\
\hline 1996 & 2974 & 735 & 24.7 \\
\hline 1997 & 3020 & 912 & 30.2 \\
\hline 1998 & 3305 & 894 & 27.0 \\
\hline 1999 & 3685 & 711 & 19.3 \\
\hline \multicolumn{4}{|c|}{ (sambungan Jadual 2) } \\
\hline Tahun & Perkahwinan & Perceraian & Peratusan Bercerai \\
\hline 2000 & 2750 & 499 & 18.1 \\
\hline 2001 & 3122 & 721 & 23.1 \\
\hline 2002 & 4172 & 798 & 19.1 \\
\hline 2003 & 4531 & 885 & 19.5 \\
\hline 2004 & 3616 & 1296 & 35.8 \\
\hline Jumlah & 87799 & 18972 & 21.6 \\
\hline
\end{tabular}


Rekod Perkahwinan Seluruh Negeri (1974-1999).

Jabatan Kemajuan Islam Malaysia, Bahagian Informasi Islam. 2000b. Fail Rekod Perceraian Seluruh Negeri (1974-1999).

Jabatan Kemajuan Islam Malaysia, Bahagian Informasi Islam. 2000c. Fail Rekod Rujuk Seluruh Negeri (1974-1999).

Jabatan Perangkaan Malaysia 2001. Ciri-ciri Pendidikan dan Sosial Penduduk, Banci Penduduk dan Perumahan Malaysia, 2000, Kuala Lumpur: Jabatan Perangkaan Malaysia.

Jabatan Kemajuan Islam Malaysia, KESUMA. 2005. Statistik Perkahwinan Seluruh Malaysia 1990-2004.

Jabatan Kemajuan Islam Malaysia, KESUMA. 2005. Statistik Perceraian Seluruh Malaysia 1990-2004.

Shaffer, David R. 2000. Social \& Personality Development. Belmont, C.A: Wadsworth/Thomson Learning.

Yaakob Harun.1992. Keluarga Melayu Bandar. Kuala Lumpur: Dewan Bahasa dan Pustaka.

Zainab Ismail. 2001. Proses Kaunseling Islam di Kalangan Pasangan Bermasalah: Kajian Kes di Unit Perunding dan Pembangunan Keluarga, JAWI. Tesis Ph.D Universiti Sains Malaysia.

Zainab Ismail \& Wan Ibrahim. 2004. Keperluan Perkhidmatan Kemanusiaan Dalam Konteks Kestabilan Perkahwinan di Kalangan Orang Melayu di Malaysia. Jurnal Islamiyyat, 25: 15 - 31.

Zainab Ismail, Ph.D

Profesor Madya

Jabatan Pengajian Dakwah dan Kepimpinan

Fakulti Pengajian Islam

43600 Universiti Kebangsaan Malaysia

Bangi, Selangor Darul Ehsan, Malaysia

zainab@pkrisc.cc.ukm.my 
mempunyai banyak kefahaman tentang hak dan tanggung jawab mereka serta tidak mempunyai kefahaman tentang hukum hakam agama dalam konteks kekeluargaan. Akan tetapi kebanyakan mereka mengakui mendapat banyak manfaat setelah menghadiri sesi kaunseling di UPPK. Klien ini didapati lebih memahami kedudukan dan peranan mereka dalam rumah tangga.

\section{KESIMPULAN}

Perceraian adalah satu isu yang masih berterusan berlaku dalam institusi keluarga di Malaysia. Isu perceraian ini didapati makin meningkat di Wilayah Persekutuan, Kuala Lumpur sejak tahun 1974 hingga 2004. Walaupun jumlah perceraian ini didapati meningkat sedikit sahaja iaitu 0.4 peratus sejak tahun 1974 hingga 2004, namun isu perceraian ini memerlukan keprihatinan semua pihak, khususnya perkhidmatan kemanusiaan. Perkhidmatan kaunseling adalah salah satu perkhidmatan kemanusiaan yang perlu disediakan kepada institusi keluarga. Melalui perkhidmatan kaunseling, klien bukan sahaja dapat meneroka masalah yang mereka alami, tetapi mereka juga dapat mengenal pasti potensi yang ada dalam diri mereka, dan dapat membuat keputusan. Dalam konteks institusi keluarga, walaupun keputusan yang diambil oleh klien didapati tidak dapat menyelamatkan rumah tangga mereka, namun pendekatan yang digunakan oleh UPPK memberi banyak manfaat kepada klien khususnya dalam konteks celik akal mengenai hukum hakam kekeluargaan, hak dan tanggung jawab suami isteri, kepentingan bersabar, dan larangan bercerai.

\section{RUJUKAN}

Abdul Malek, A. al-Sayed. 1995. Etika Sosial dalam Islam. Kuala Lumpur: Dewan Bahasa dan Pustaka.

al-Faruqi, Ismail \& Lois Lamy. 1986. The Cultural Atlas of Islam. New York: Macmillan Publishing Company.

cAbd al-Karim Zaid.1997. Us l lal-Dac wah. Ed.6. Beirut: al-Resalah Pub. House. Hassan Langgulung.1990. Kaunseling dalam Masyarakat Islam. Kertas kerja Seminar Kaunseling dalam Masyarakat Islam. Yayasan Dakwah Islamiah Malaysia, Kuala Lumpur, 25-26 September.

Ibn Khald, n, ${ }^{c}$ Abd al-Rahm\%on ibn Muhammad.1981. Muqaddimah. Jil. 2. Q\%ohirah: D\%or al-Nahdah.

Jabatan Kemajuan Islam Malaysia, Bahagian Informasi Islam. 1998a. Fail Rekod Perkahwinan Seluruh Negeri (1980-1993).

Jabatan Kemajuan Islam Malaysia, Bahagian Informasi Islam. 1998b. Fail Rekod Perceraian Seluruh Negeri (1980-1993).

Jabatan Kemajuan Islam Malaysia, Bahagian Informasi Islam. 1998c. Fail Rekod Rujuk Seluruh Negeri (1980-1993).

Jabatan Kemajuan Islam Malaysia, Bahagian Informasi Islam. 2000a. Fail 